
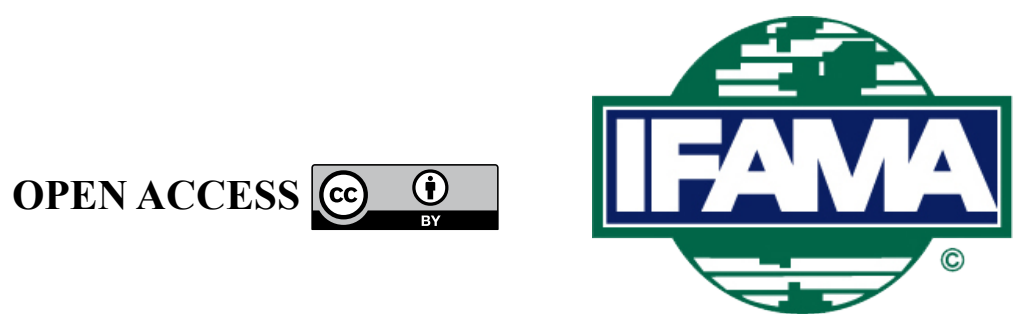

International Food and Agribusiness Management Review

Volume 25, Issue 3, 2022; DOI: 10.22434/IFAMR2021.0059

Received: 11 May 2021 / Accepted: 9 December 2021

\title{
The apparent conflict of Norwegian pelagic fisheries management and Norwegian seafood council export promotion
}

RESEARCH ARTICLE

\author{
Gary W. Williams ${ }^{\mathrm{a}}$ and Oral Capps, Jr. ${ }^{\circledR b}$ \\ ${ }^{a}$ Professor and Co-Director of the Agribusiness, ${ }^{b}$ Executive Professor and Regents Professor, \\ Co-Director of the Agribusiness, Food and Consumer Economics Research Center, \\ Department of Agricultural Economics, Texas A\&M University, College Station, TX 77843-2124, USA
}

\begin{abstract}
The Norwegian government operates pelagic fishery management systems designed to avoid overfishing and foster sustainable annual landings while at the same time managing an export promotion program designed to increase foreign sales of herring and mackerel. Simultaneously promoting foreign sales of pelagic fish and limiting the availability of those fish for sale are policies in apparent conflict. This research demonstrates, however, that effective limits on the availability of pelagic fish for export tend to complement the profitenhancing export promotion objectives of the Norwegian Seafood Council (NSC) for the Norwegian herring and mackerel industries. Assuming highly (but not perfectly) effective limits on herring and mackerel exports arising from their respective fishery management systems over the 2003 to 2018 period of analysis, NSC herring and mackerel export promotion contributed 5-7\% to Norwegian herring export revenue and industry profit, respectively and $11-15 \%$ to Norwegian mackerel export revenue and industry profit, respectively. Less effective limitation on Norwegian herring and mackerel export supplies would erode the respective industry revenue and profit gains from NSC export promotion. In essence, the NSC effectively exploits the limits on herring and mackerel export availability imposed by Norwegian fishery management systems for the benefit of Norwegian herring and mackerel industries.
\end{abstract}

Keywords: Norway, pelagic fisheries management, Norwegian Seafood Council, export promotion, econometric simulation, benefit-cost analysis

JEL code: Q22, Q27, Q28

\footnotetext{
(i)Corresponding author: ocapps@tamu.edu
} 


\section{Introduction}

Pelagics comprise several diverse fish species, including Atlantic mackerel, herring, blue whiting, capelin, Atlantic horse mackerel, sandeel, sprat, and Norway pout, among others. Norwegian pelagic fisheries have a storied history highlighted by the overfishing-induced collapse of the Norwegian spring-spawn herring stock in the late 1960s (Gordon and Hannesson 2015; Gullestad et al., 2014). In the ensuing years, Norway's pelagic fishery management systems ${ }^{1}$ evolved slowly in conjunction with ongoing negotiations among neighboring coastal states to arrive at a complex set of regulatory measures intended to repel the continual onslaught of economic forces, including enhanced production efficiency and growing global demand, on the long-run sustainability of the fisheries (Gullestad et al., 2014).

As Norway struggled to develop effective limits on its catch of pelagic fish over the years, however, the Norwegian government launched a program in 1991 intended to promote world-wide demand for Norwegian seafood. ${ }^{2}$ Under the program, the Norwegian Seafood Council (NSC), a public company owned by the Norwegian Ministry of Trade, Industry and Fisheries, targets primarily the Norwegian catch or production of salmon, whitefish (Atlantic cod, saithe, and haddock), and pelagics for export promotion. Among pelagic species, the NSC primarily targets exports of mackerel and herring, including both North Sea herring and Norwegian spring-spawn herring, for promotion. Other pelagic species are not NSC targets for export promotion because they are primarily demanded for processing (reduction) into fish meal as a protein supplement in livestock and farmed fish rations (Miles and Chapman, 2006) and fish oil.

The promotional activities of the NSC are financed by levies on seafood exports delineated by species (Norwegian Seafood Council, 2019). The pelagic fish export levy rose from $0.30 \%$ between 2003 and 2009 up to $0.50 \%$ in 2010 and then to $0.75 \%$ a year later. The levy was reduced to $0.60 \%$ in 2017 and again to $0.30 \%$ in 2017 and 2018. Like numerous other generic promotion programs around the world for generally homogenous commodities (e.g. Colombian coffee, Mexican avocados, U.S. wheat and soybeans, New Zealand lamb, and many more), NSC seafood export promotion is a cooperative effort paid for by industry suppliers to enhance their individual and collective profitability (Ward, 2006; Williams and Capps, 2006). The primary goal of such generic promotion is to enhance the market demand for the promoted commodity in an effort to raise the sales volume and price for the benefit of those who pay for the promotion (the stakeholders). Brand advertising, on the other hand, seeks to differentiate the product of a specific firm from those of other firms in related markets in an effort to boost the product's market share and sales (Kinnucan and Clary, 1995; Williams and Capps, 2006).

The intensifying regulatory efforts by Norway in cooperation with other countries to avoid overfishing in pelagic fisheries and thereby foster a sustainable annual pelagic fish catch would seem to be in conflict with the simultaneous, aggressive effort of the Norwegian government to promote foreign sales of herring and mackerel. If catch limits are effectively implemented, then promoting exports of herring and mackerel would seem to be a futile, losing proposition for stakeholders. Otherwise, the export promotion incentivizes overfishing and undermines the attainment of the respective fishery management system objectives. What, then, have been the effects of NSC promotion of mackerel and herring exports over the years? Have the stakeholders in the Norwegian herring and mackerel industries realized any economic benefits from the NSC export promotion programs that the levies finance? This article explores the answers to these and related questions, analyzing the export market effects and returns to stakeholders from NSC pelagic export promotion over time in the context of the catch limits established under Norwegian pelagic fish management systems. The domestic Norwegian market for pelagics accounts for a small percentage of the Norwegian pelagic fish catch and, thus, is not considered in this analysis. Following a brief background on Norwegian herring

\footnotetext{
${ }^{1}$ Hoggarth et al. (2006) define a fishery management system as 'activities designed to ensure the rational and responsible use of living marine resources ... [which] may include governance arrangements (policy, legal instruments, use rights, control systems, etc.), management procedures (setting objectives, control rules, performance measures, reference points, etc.), scientific advice (stock assessment methods, management scenario modelling, etc.), compliance (surveillance and enforcement, voluntary codes, incentive structures, etc.), and monitoring.'

2 The term 'seafood' includes both captured and farmed seafood. The term 'seafood industry' includes both fisheries and aquaculture.
} 
and mackerel exports and corresponding NSC export promotion expenditures, relevant economic studies regarding Norwegian herring and mackerel are reviewed. The methodology, data used, and analytical results are then discussed. Finally, the main conclusions are summarized and key policy implications are highlighted.

\section{Background on Norwegian herring and mackerel exports and promotion}

\subsection{Norwegian herring and mackerel exports}

After a long period of general increase that began in the early 1990s, the stock of Norwegian spring-spawn herring and, thus, the Norwegian herring quotas and catch, began declining in 2010 resulting in a sharp drop in Norwegian herring exports from a high of nearly 762,000 metric tons (mt) in 2009 to a low of a little over $216,000 \mathrm{mt}$ in 2015, a drop of over 70\% (Norwegian Seafood Council 2019, 2020). Norwegian herring exports were dealt a further blow in 2014 when Russia, the largest export market for Norwegian herring, closed its markets as part of its response to the Western embargo on Russian trade during the Crimea-Ukraine conflict (Andersen et al., 2009; Nilssen and Elvestad, 2019). The Norwegian herring catch generally reflected the established quota levels over 2003 to 2018 , varying between $3 \%$ below and $13 \%$ above the annual quota levels (average 7\% above) (Figure 1). Herring exports, however, were consistently below the catch levels over that period, varying between 28 and $48 \%$ below (an average of $36 \%$ below) the annual catch levels.

Historically, a large share of the annual herring catch has been destined for reduction to fishmeal and oil. Between 2003 and 2018, however, an average of only about 6\% was used for that purpose (Statistics Norway, 2019). Seasonality of the herring catch creates seasonality in Norwegian herring exports with the peak from October to March and a smaller summer peak around June. With the quota and catch reductions after 2010, the seasonal swings became increasingly tempered.

Reduction to fishmeal and oil was the predominant usage of mackerel in past years. However, more than $99 \%$ was used for human consumption between 2003 and 2018 (Statistics Norway, 2019). The catch generally exceeded the established quotas over that period by as much as $60 \%$ in some years (Figure 2). Norwegian mackerel exports as a share of the catch, however, averaged about $97 \%$ over the same period on a live weight basis (Norwegian Seafood Council, 2019). Norwegian mackerel exports remained just under 200,000 mt from 2003 until 2009, much below the level of herring exports (compare Figures 1 and 2). A 130\% increase

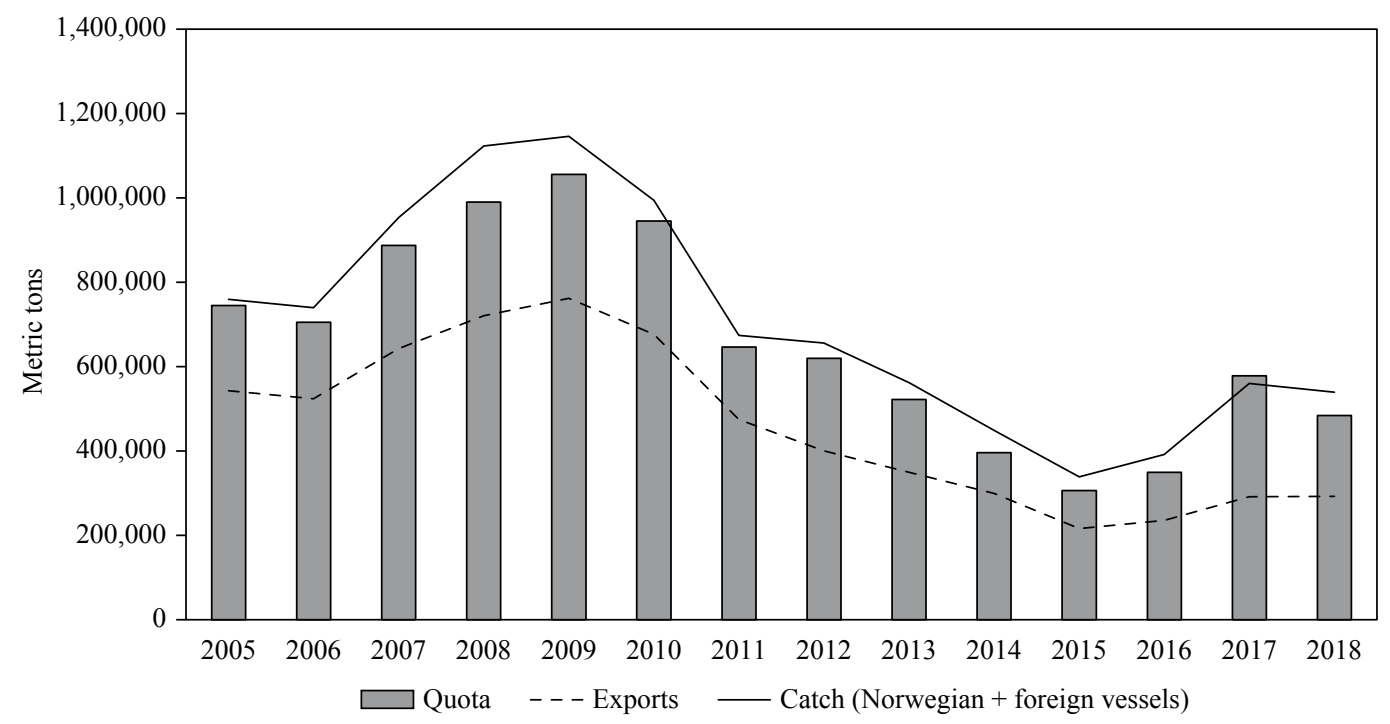

Figure 1. Norwegian herring (North Sea and Spring-Spawn) quota, catch, and exports (live weight), 20052018. Developed with data from NSC (2019). 


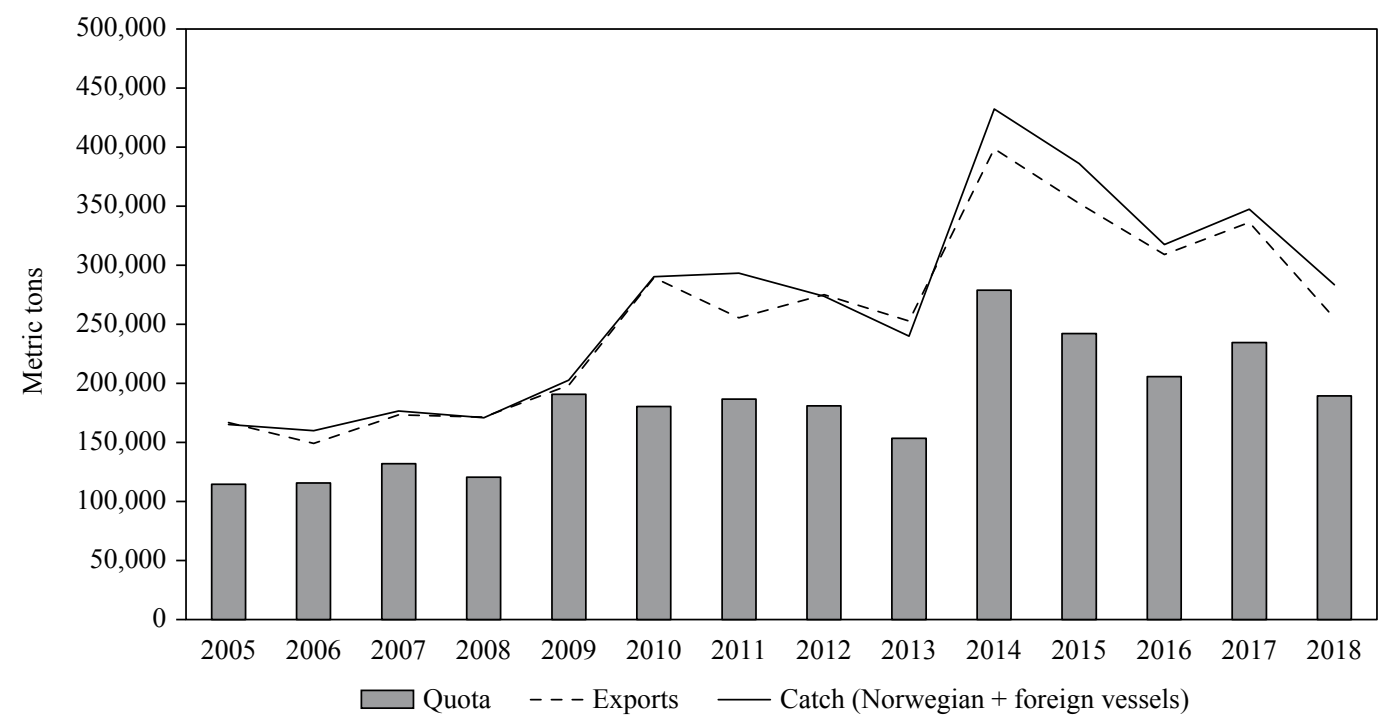

Figure 2. Norwegian mackerel quota, catch, and exports (live weight), 2005-2018. Developed with data from NSC (2019).

in Norway's mackerel quota and catch between 2008 and 2014 allowed foreign countries to purchase more mackerel, pushing Norwegian mackerel exports up by a corresponding $133 \%$ to nearly $400,000 \mathrm{mt}$ over that period. A reversal of the mackerel quota and catch after 2014 again restricted export availability leading to a $36 \%$ drop in annual mackerel exports to about $255,000 \mathrm{mt}$ by 2018 . Norwegian mackerel exports tend to spike around the time of harvest (September to December).

\subsection{Norwegian seafood council herring and mackerel export promotion}

Headquartered in Tromsø, Norway, the NSC is charged with increasing the demand for Norwegian seafood in key markets around the world. The NSC works closely with the seafood industry to identify and develop markets for Norwegian seafood products. From 2003 to 2018, NSC expenditures to promote herring and mackerel amounted to NOK (Norwegian Kroner) 519.5 million (US\$77.0 million), almost evenly divided between the two pelagic species (51.9 and 48.1\%, respectively) (Figure 3). Between 2003 and 2013, however, total expenditures to promote herring (NOK 199.3 million (\$US 33.4 million)) were roughly twice those for mackerel (NOK 98.5 million (US\$ 16.3 million)). Then, with the decline in the herring quota, catch, and exports and the closure of the Russian market for Norwegian herring between 2014 through 2018, promotion expenditures for mackerel (NOK 151.4 million (US\$ 18.7 million)) were slightly more than double those for herring (NOK 70.2 million (US\$ 8.6 million)). Between 2003 and 2013, Russia, Poland, and the Ukraine dominated NSC herring export promotion expenditures, accounting for over $70 \%$ of the NOK 142.9 million in NSC herring export promotion expenditures. With the loss of its primary herring promotion target markets in 2014, the NSC redirected remaining funds to develop and build herring markets across a more diverse set of countries, including Germany, Belarus, Denmark, and the United States, among others (Norwegian Seafood Council, 2019).

Japan accounted for over 80\% of NSC mackerel export promotion investments between 2003 and 2010. South Korea became a major NSC mackerel promotion target in 2011 and accounted for $44 \%$ of NSC mackerel export promotion spending by 2015. Japan accounted for most of the remainder. NSC herring and mackerel export promotion spending exhibited definite but distinct seasonality patterns between January 2003 and December 2018. Price inflation in major foreign markets along with a depreciation of the NOK relative to foreign currencies over that period combined to erode the real purchasing power of NSC promotion expenditures. Norwegian herring and mackerel promotion expenditures averaged only $0.5 \%$ of their export values over that period, a common characteristic of export promotion programs (Kinnucan and Cai, 2011). 


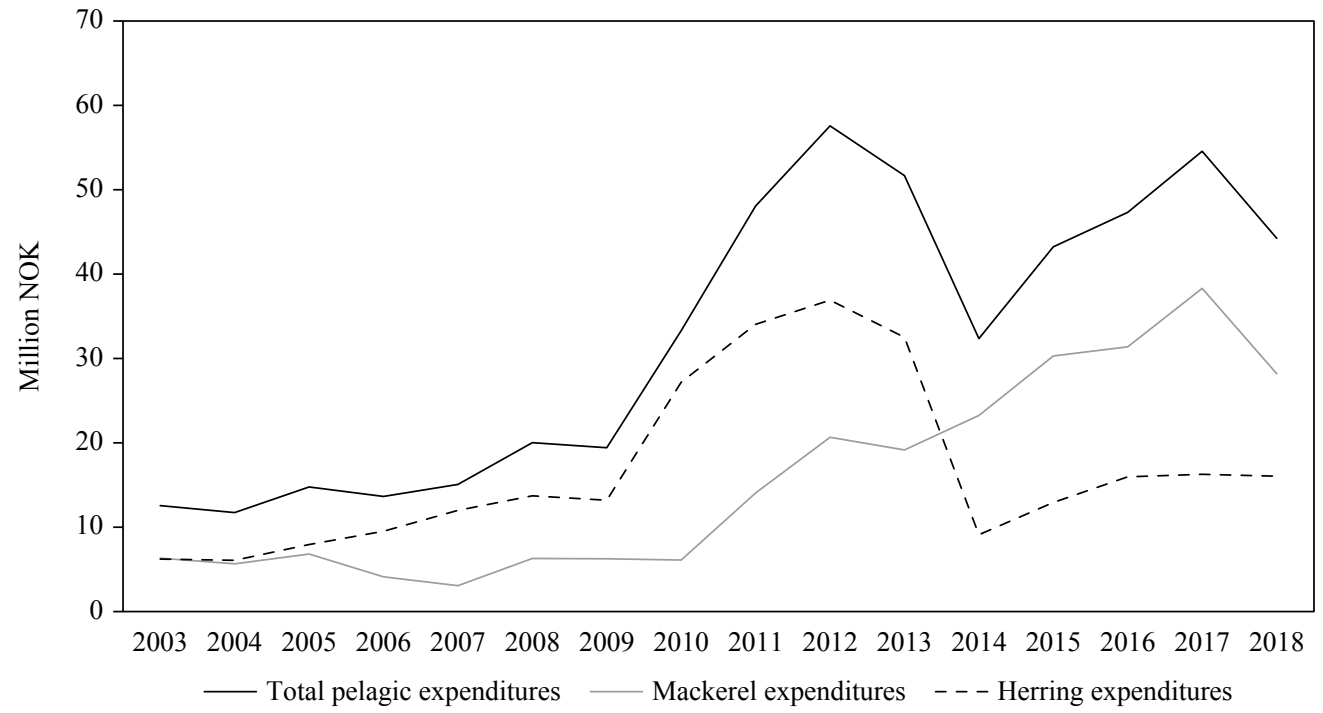

Figure 3. Nominal NSC herring and mackerel export promotion expenditures, 2003-2018. Developed with data from NSC (2019).

\section{Previous research}

The literature on Norwegian pelagic fishery economics is sparse. Most bioeconomic studies of fish supply have assumed that price is exogenous (Nostbakken and Biorndal, 2003). A few studies have considered the shape of the Norwegian herring supply curve but have provided no estimates of the supply elasticity (Biorndal and Conrad, 1987; Nostbakken, 2008; Nostbakken and Biorndal, 2003). Their general conclusion is that the regulatory regime and biophysical factors are the most important determinants of the Norwegian herring supply. On the demand side, a few studies considered Russian herring consumer preferences before the closure of that market (e.g. Tveteras et al., 2011) and the substitutability of Norwegian herring for various fish species, including Danish herring (Nielsen, 2004) and anchovies in the European market (Nielsen et $a l ., 2009,2012)$. No previous research has estimated the price or income elasticities of Norwegian herring or mackerel export demand.

NSC herring and mackerel export promotion programs have not been studied. Extensive analyses of NSC salmon export promotion, however, have reported wide-ranging promotion elasticities ( 0.01 to 0.054$)$ as well as benefit-cost ratios (BCRs) (-0.08 to 9.53) (e.g. Kaiser, 2015; Kinnucan and Myrland, 2000, 2001, 2002, 2003, 2006; Myrland and Kinnucan, 2000; Xie, 2008, 2015; Xie et al., 2009). Williams and Capps (2020b) concluded that NSC whitefish export promotion boosted Norwegian whitefish export price by more than volume ( 6 and $2 \%$, respectively) resulting in a promotion BCR of 5.9. For the overall NSC seafood export promotion program, Williams and Capps (2020b) find slightly higher export volume and price effects (4 and $10 \%$, respectively) and a higher promotion BCR than for whitefish of about 12 to 13 .

\section{Methodology and data}

A three-equation conceptual model for Norwegian pelagic fish exports is postulated to investigate the effectiveness of NSC pelagic fish promotion in the context of Norwegian fishery management:

$$
\begin{aligned}
& \operatorname{NPXD}_{\mathrm{jt}}=\mathrm{f}\left(\mathrm{NPPX}_{\mathrm{jt}}, \mathrm{G}_{\mathrm{jt}}, \mathrm{ZD}_{\mathrm{jt}}\right) \\
& \mathrm{NPXS}_{\mathrm{jt}}=\mathrm{g}\left(\mathrm{NPPX}_{\mathrm{jt}} /(1+\lambda)_{\mathrm{jt}}, \mathrm{ZS}_{\mathrm{jt}}\right) \\
& \mathrm{NPXS}_{\mathrm{jt}}=\operatorname{NPXD}_{\mathrm{jt}}
\end{aligned}
$$


where for each pelagic fish $\mathrm{j}$ (= herring, mackerel), NPXD = aggregate foreign demand; NPXS = Norwegian export supply; NPPX = average price paid for exports; $\lambda=a d$ valorem promotion levy assessed by NSC on pelagic fish exports; $\mathrm{NPPX}_{\mathrm{t}} /(1+\lambda)_{\mathrm{t}}=$ the price received by Norwegian exporters $\left(=\mathrm{NPP}_{\mathrm{j}}\right) ; \mathrm{G}=$ 'goodwill' or promotion stock variable representing NSC export promotion expenditures (see Nerlove and Arrow, 1962); $\mathrm{ZD}=$ all other demand shift variables, including income as well as inflation rates and exchange rates relative to the NOK of importing countries, export prices of other pelagic fish, inflation, and qualitative events affecting Norwegian pelagic exports; ZS is an equivalent matrix of supply shift variables; and t corresponds to monthly time period.

\subsection{Econometric equations and data used for Norwegian herring and mackerel export demand}

Two econometric representations of Equation 1 were developed in which the dependent variables were, respectively, the export demands for Norwegian herring (aggregated over spring-spawn and North Sea herring) and Norwegian mackerel over 2003 through 2018. The specification of each equation follows that of Kaiser (2015), Williams and Capps (2020b), and Williams et al. (2016). The monthly export unit values of Norwegian exports of herring and mackerel are the export price variables (NPP) in their respective equations. NSC provided monthly data on Norwegian herring and mackerel export volume and value (Norwegian Seafood Council, 2019). The export price (NPP) for each species was multiplied by a monthly trade-weighted exchange rate index in foreign currency per NOK (base period 2010) for each species to account for changes in currency values against the NOK. The trade-weighted NOK exchange rate index for each species was developed using the exchange rates for each species across the top ten importing countries of each species from the International Financial Statistics (IFS) of the International Monetary Fund (IMF, 2019) using monthly trade weights calculated from the respective monthly Norwegian export data for each species provided by NSC (Norwegian Seafood Council, 2019). The exchange-rate-adjusted export prices of herring and mackerel were then deflated by the FAO pelagic price index (developed by Tveterås, personal communication) and updated by Tveterås (2017) to account for competing global prices of pelagic fish. The use of the ratio of the exchange-rate-adjusted prices of herring and mackerel to the FAO pelagic price index also mitigates any potentially degrading collinearity problems.

Changes in consumer purchasing power in Equation 1 for each species are represented by the inflationadjusted and exchange-rate-adjusted gross domestic products (GDPs) aggregated over the top ten importing countries. The GDPs of those countries for each species were collected from the IFS (2019), converted to NOK, deflated by an aggregate trade-weighted consumer price index (base period 2010) for the same countries for each species from IFS (IMF, 2019), multiplied by the trade weights for each species, and aggregated into a single real GDP measure for each month. To account for changes in currency values, the real aggregate GDP measures for each species were then multiplied by the monthly trade-weighted exchange rate index for the respective species.

The goodwill variable G in Equation 1 for each species are the NSC herring and mackerel export promotion expenditures which have been transformed to represent common characteristics of the relationship between promotion expenditures and export demand. First, the X13 technique in EVIEWS 11.0 (IHS Global Inc., Irvine, CA, USA) was used to seasonally adjust the promotion expenditures data for each species to avoid confounding associated with Norwegian herring and mackerel export seasonality. Next, the promotion expenditures were exchange-rate-adjusted and inflation-adjusted as done for the GDP variable used in Equation 1 for each species. Finally, although the literature is replete with evidence that promotion expenditures have carryover or lagged effects (e.g. Forker and Ward, 1993; Ghosh and Williams, 2016; Lee and Brown, 1986; Nerlove and Waugh, 1961; Ward and Dixon, 1989; Williams and Capps, 2020a,b,c; Williams et al., 2014), little guidance is provided on the structure and length of the dynamic process. Following a common practice in the literature, the Almon polynomial distributed lag (PDL) formulation was used to econometrically measure the time lag in the effect of NSC export promotion expenditures on Norwegian herring and mackerel export demands. 
Measuring the pattern, polynomial degree, and period over which promotion expenditures influence Norwegian herring and mackerel export demands involved a series of nested OLS regressions. As commonly done, model selection criteria, including the Akaike Information Criterion, the Schwarz Loss Criterion, were used to determine the optimal number of lags to include in the specification. Given previous research suggesting that the total impact of promotion expenditures in a given month occurs within a year following the expenditure, lags of NSC promotion expenditures of up to twelve months were considered. The econometric analysis measures the short-run and long-run (cumulative) effects as well as the average number of months before changes in NSC export promotion expenditures begin affecting Norwegian export demands for herring and mackerel. Also, a logarithmic transformation of the exchange rate-adjusted, deflated, and seasonally adjusted NSC export promotion expenditures for each species was implemented to account for the effects of diminishing marginal returns associated with the problem of advertising wear out (Kinnucan et al., 1993) as commonly done (e.g. Williams et al., 2016).

Norwegian herring and mackerel export markets are largely independent given that the two species are demanded by different sets of countries. Thus, the two pelagic fish were not treated as substitutes in the econometric analysis. The effects of habit persistence (inertia) in exports of each pelagic fish were captured using a one-month lag of the exports of each in their respective export demand equations. The seasonal patterns evident in monthly herring and mackerel exports were also accounted for using monthly indicator variables. Finally, a number of qualitative events affecting world pelagic markets in particular months and years were identified and treated as indicator variables in Equation 1 for the respective species.

\subsection{Norwegian herring and mackerel export supply price response}

The Norwegian herring and mackerel export supply responses to changes in their respective export prices are represented by Equation 2. The critical link between the export supply elasticity and the effectiveness of export promotion is illustrated for a given pelagic fish (herring or mackerel) in Figure 4. Assume that NSC promotion shifts out the export demand for the pelagic fish in a given period from NPXD ${ }^{\text {wo }}$ to NPXD ${ }^{\mathrm{w}}$ (wo and w signify 'without' and 'with' promotion, respectively). The ad valorem levy on Norwegian pelagic fish exports $(\lambda)$ behaves like an excise tax whose cost is shared by producers and consumers (Chang and Kinnucan, 1991). The tax creates a gap between the price paid by foreign consumers (NPPX in the model) and the price received by Norwegian exporters $(\mathrm{NPP}=\mathrm{NPPX} /(1+\lambda))$ at any given level of Norwegian exports of the pelagic fish (NPX). Thus, the export supply curve representing prices paid by importers (NPXS $(\lambda)$ ) is vertically separated by the levy from the export supply curve representing the prices received by Norwegian exporters (NPXS) as shown in Figure 4. For clarity of exposition and to focus the discussion on Norway, the prices received by Norwegian exporters (NPP) are highlighted in Figure 4.

If the Norwegian fishery management system creates an absolute limit on annual export supplies of the pelagic fish, then the export supply would be represented graphically as a vertical or perfectly inelastic export supply curve like NPXSi in Figure 4. Thus, the promotion-induced shift of the export demand curve results in no increase of the quantity exported rendering the promotion program unsuccessful in terms of export enhancement. Even so, the export demand curve shift boosts both the price received by Norwegian exporters of the pelagic fish ( $\mathrm{NPP}_{0}^{\mathrm{WO}}$ to $\mathrm{NPP}_{\mathrm{i}}^{\mathrm{W}}$ ) and industry export revenue (shaded rectangle). Given that export demand promotion does not affect export volume, the costs of export suppliers do not change either. Thus, the NSC-induced increase in export revenue is also the increase in export surplus ${ }^{3}$ and the net benefit to the Norwegian pelagic fish industry in this case. The domestic Norwegian market accounts for a small percentage of the Norwegian pelagic fish catch so that export surplus approximates Norwegian pelagic fish producer surplus. Thus, export surplus is considered here as a measure of producer surplus and, although not exactly the same thing, deemed a measure of the addition to the profit of the Norwegian pelagic fish industry from export promotion.

\footnotetext{
3 'Export surplus' is defined as the difference between the gain in producer surplus and the loss in consumer surplus and, thus, the net gain to an exporting country from an increase in exports.
} 


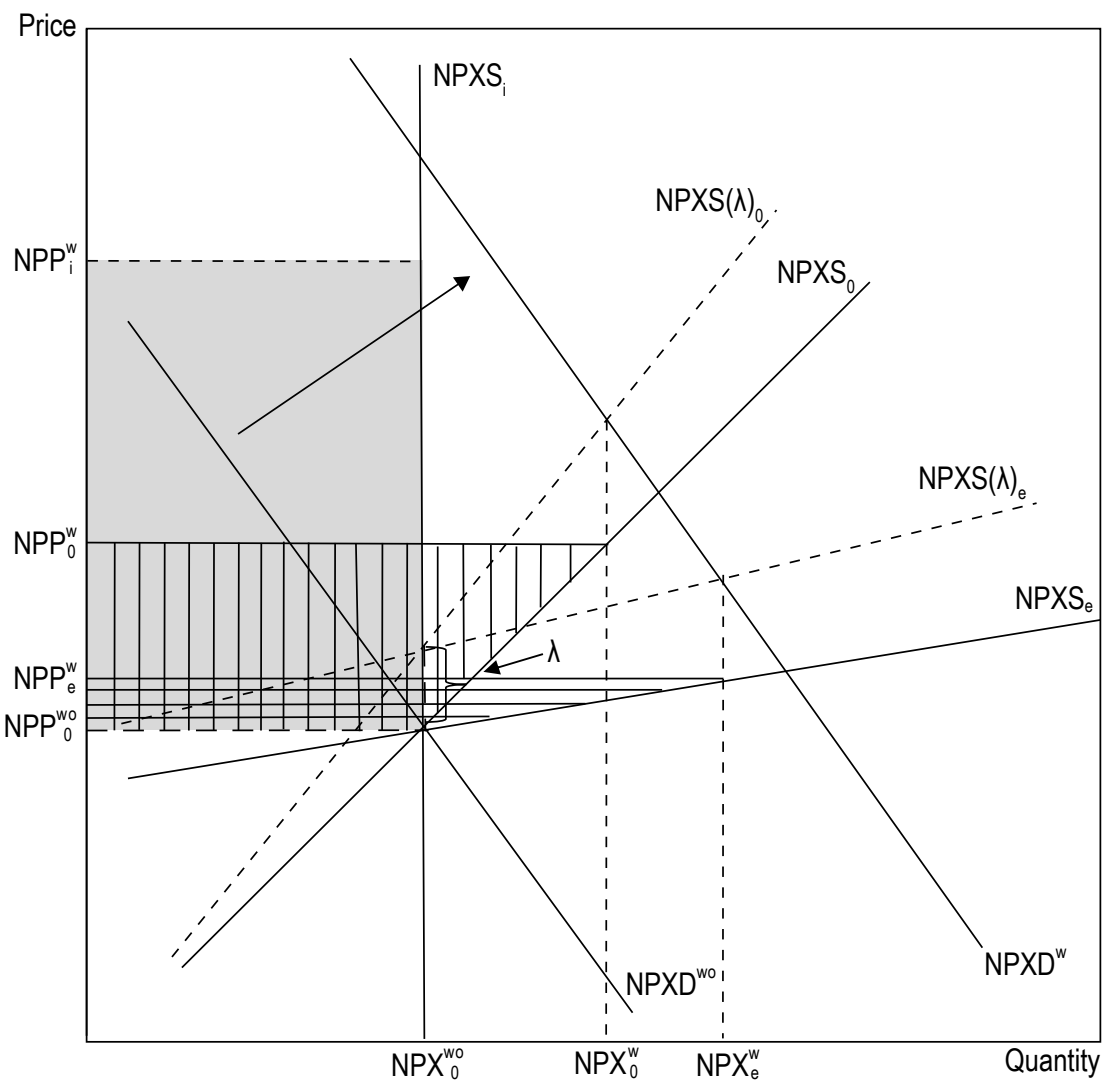

Figure 4. Effects of fishery management export limitations on export promotion effectiveness.

A more price-elastic export supply, such as $\mathrm{NPXS}_{0}$ in Figure 4, represents less-effective limits under this Norwegian pelagic fishery management system on the Norwegian supplies of the pelagic fish available for export. Thus, a promotion-induced increase in foreign pelagic fish demand results in some increase in export volume (NPX ${ }_{0}^{\mathrm{Wo}}$ to $\mathrm{NPX}_{0}^{\mathrm{W}}$ ) but a smaller increase in the export price $\left(\mathrm{NPP}_{0}^{\mathrm{Wo}}\right.$ to $\mathrm{NPP}_{0}^{\mathrm{W}}$ ) than with a completely export-limiting fishery management system. The increase in export surplus or profit to the industry (the area lined vertically in Figure 4) is smaller as a result.

Alternatively, given little or no limit on the export supplies of the pelagic fish under its fishery management system as represented by an elastic export supply curve such as NPXS in Figure 4, the main result of a successful promotion program is an increase in the export volume $\left(\mathrm{NPX}_{0}^{\mathrm{WO}}\right.$ to $\mathrm{NPX}_{\mathrm{W}}^{\mathrm{W}}$ ) rather than in the export price (NPP ${ }_{0}^{\mathrm{WO}}$ to $\mathrm{NPP}_{\mathrm{e}}^{\mathrm{W}}$ ). Even though the export price increase is diminished by the robust export supply response in this case, the export revenue is higher than without promotion because the higher volume of exports sell at a slightly higher export price. As exports increase with promotion, the total cost of exporting also increases, Thus, the increase in the net benefit (profit) to the industry (the horizontally-lined area in Figure 4) from promotion is smaller than the corresponding export revenue increase. The increase in industry profit from export promotion is always positive unless the export supply curve is perfectly elastic.

Even though fish supplies and, thus, the supplies of fish available for export, often are assumed to be exogenously determined, Norwegian pelagic export supplies may be at least somewhat responsive to price changes over the long-run for several reasons. First, overfishing established quotas has been a problem over the years, particularly for mackerel, and may well be the result of high prices and profits in some years to some degree (Gullestad et al., 2014). Pitcher et al. (2009) report that Norway's compliance with the UN Code of Conduct for Responsible Fisheries (Food and Agriculture Organization, 1995), which sets standards intended to reduce overfishing, is the highest among countries but rate Norway's compliance at only $60 \%$. 
Second, the Norwegian herring catch levels apparently were not constrained by the total allowable catch (TAC) limit in most years over the 2003-2018 period of analysis. Thus, price and profit-seeking likely played some role in Norwegian herring export supply changes over those years. NSC promotion has likely helped push herring catch levels over those years towards the TAC limits by enhancing demand.

Third, herring and mackerel export supplies are not the same thing as their catch levels. Export supply curves are usually more elastic than domestic supply and demand curves given that they are constructed as the difference between them. Norway exported $97 \%$ of its mackerel catch and about $64 \%$ of its herring catch (live weight basis). Thus, no matter how strictly their respective fishery management systems control their catch levels, an export price increase of either pelagic fish (but herring, in particular) can increase the supply available for export to some extent by siphoning off some of the supply available to the small, robust domestic market and to other uses.

Finally, the national quotas levels set for the two pelagic species in some years may have been influenced by price trends (Nostbakken, 2008). In principle, the International Council for the Exploration of the Seas (ICES) provides scientific advice each year on the recommended TAC and then Norway and the other 19 ICES member countries set their individual catch quotas per agreement with other countries (ABPmer, 2018). Long-running disputes over the last decade or more, however, regarding herring and mackerel stocks have led to changes in the proportion of the TAC claimed for each by various countries at various times resulting in breakdowns of quota sharing arrangements (Gullestad et al., 2014). The result often has been unilateral TAC-setting and fishing over the advised sustainable levels. For example, over the period of 2009 to 2017, the sum of the Atlantic mackerel catch quotas set by the various countries involved was $150 \%$ of ICES scientific advice (ABPmer, 2018). For Norwegian spring-spawn herring, a TAC has not been agreed among countries since 2012 with overall quotas set above scientific advice (ABPmer, 2018). During such times, fish production becomes more competitive and, thus, potentially more price responsive. Fish supplies can become completely unresponsive to price only when countries enter into strictly enforced cooperative agreements to limit supply.

Although assuming absolute unresponsiveness of the Norwegian herring and mackerel export supply curves is not reasonable, they are not likely to be elastic either. The annual catch of herring since 2006 is just about equal to the national quota and nearly all of the annual catch of mackerel is exported each year (Figures 3 and 4). Following the work of Williams and Capps (2020b), the simulation analysis that follows assumes export supply elasticities of 0.5 for species. The results for a range of alternative export supply elasticities are presented by way of comparison and to provide insights on the economic consequences for both pelagic fish industries of more or less effective export supply controls under their respective fishery management systems.

\subsection{Counterfactual (simulation) analysis procedure}

Using the model represented by Equations 1-3 and the econometric parameters estimated for Equation 1 for each species, two initial scenarios were simulated over the study period (January 2003 through December 2018) assuming export supply elasticities of 0.5 for both species: (1) 'with NSC export promotion' simulations (the 'with' scenarios); and (2) 'without NSC export promotion' simulations (the 'without' scenarios). For comparison purposes, additional simulations were done assuming: (1) perfectly inelastic export supplies (absolute supply controls); and (2) higher export supply elasticities (1.0, 1.5 and 2.0) representing progressively less effective fishery management system limitations on export supplies.

The 'with' scenarios for both herring and mackerel represent history, i.e. the actual Norwegian export volumes, values, and prices for the respective pelagic fish which include the effects of NSC promotion over the study period. In the 'without' scenario analyses, NSC export promotion expenditures for each species in Equation 1 and the export levy $(\lambda)$ in Equation 2 first were set to zero. Then the model was simulated again to determine the new levels of herring and mackerel export volumes, prices, and values that represent what would have occurred without NSC promotion over the study period assuming an export supply elasticity of 0.5. 
The comparison 'without' scenarios were conducted in the same manner. The differences between the simulated levels of Norwegian herring and mackerel export volumes, values, and prices in the 'with' scenarios from those in their respective 'without' scenarios are direct measures of the effects of the NSC herring and mackerel export promotion programs. No exogenous variable in the model other than the NSC mackerel and herring promotion expenditures and the levy were allowed to change in their respective 'without' scenarios.

\subsection{Return on investment calculations}

The most common metric used to evaluate the export promotion return to stakeholders is the benefit-cost ratio (BCR) (Nerlove and Arrow, 1962). In calculating export promotion program BCRs, a commonly used measure of the 'benefit' of promotion is the promotion-induced addition to export revenue. For a given export supply elasticity, the simulated additions to Norwegian herring and mackerel export revenue (RX) generated by the respective NSC export promotion expenditures are calculated as:

$$
\mathrm{RX}_{\mathrm{jt}}=\mathrm{NPP}_{\mathrm{jt}}^{\mathrm{w}} \mathrm{NPX}_{\mathrm{jt}}^{\mathrm{w}}-\mathrm{NPP}_{\mathrm{jt}}^{\mathrm{wo}} \mathrm{NPX} \mathrm{jt}_{\mathrm{jt}}^{\mathrm{wo}}
$$

where $\mathrm{j}=\{$ herring, mackerel $\}$ and $\mathrm{t}=$ month.

The gross revenue BCR (GBCR) is calculated by dividing the sum of the $\mathrm{RX}_{\mathrm{jt}}$ by the sum of the NSC promotion expenditures $(\mathrm{E})$ over time:

$$
\mathrm{GBCR}_{\mathrm{j}}=\frac{\sum_{\mathrm{t}-1}^{\mathrm{T}} \mathrm{RX}_{\mathrm{jt}}}{\sum_{\mathrm{t}-1}^{\mathrm{T}} \mathrm{E}_{\mathrm{t}}}
$$

for the assumed export elasticity where T represents the last month of the study period.

Because NSC promotion is a cost to stakeholders, promotion expenditures in each period subtracted from $\mathrm{RX}$ which yields the net export revenue BCR for each pelagic fish $\mathrm{j}$ for the assumed export supply elasticity:

$$
\mathrm{NBCR}_{\mathrm{j}}=\frac{\sum_{\mathrm{t}-1}^{\mathrm{T}}\left(\mathrm{RX}_{\mathrm{jt}}-\mathrm{E}_{\mathrm{t}}\right)}{\sum_{\mathrm{t}-1}^{\mathrm{T}} \mathrm{E}_{\mathrm{t}}}
$$

Even though revenue generation is often a goal of export promotion, revenue-based export BCR measures are misleading because the additional costs required to generate the additional export revenue are ignored. As discussed earlier, the change in export surplus (RS) is a more appropriate measure of the 'benefit' to stakeholders from promotion. As illustrated in Figure 4, the RS of NSC promotion for each pelagic fish $\mathrm{j}$ in period $\mathrm{t}$ is calculated as:

$$
\mathrm{RS}_{\mathrm{jt}}=\left(\mathrm{NPP}_{\mathrm{jt}}^{\mathrm{w}}-\mathrm{NPP}_{\mathrm{jt}}^{\mathrm{wo}}\right) \mathrm{NPX}{ }_{\mathrm{jt}}^{\mathrm{wo}}+1 / 2\left(\mathrm{NPX}_{\mathrm{jt}}^{\mathrm{w}}-\mathrm{NPX}_{\mathrm{jt}}^{\mathrm{wo}}\right)\left(\mathrm{NPP}_{\mathrm{jt}}^{\mathrm{w}}-\mathrm{NPP}_{\mathrm{jt}}^{\mathrm{wo}}\right)
$$

The net export surplus BCRs (SBCRs) are calculated by replacing $\mathrm{RX}_{\mathrm{jt}}$ with $\mathrm{RS}_{\mathrm{jt}}$ in Equation 6 .

As discussed earlier, export surplus can be considered to be an industry profit measure.

Importantly, we analyze the case of the historical (exogenous) Norwegian Seafood Council (NSC) promotion of herring and mackerel exports. NSC expenditures and, thus, the levy, are assumed to be exogenous (rather than endogenous when calculating the optimality conditions) over time because they have already occurred. The objective of the analysis is not to determine, given the price elasticity of demand and the elasticity of promotion, whether the level of expenditures over time were optimal (producer-welfare-maximizing) as done by Kinnucan and Myrland (2000). Rather, our analysis considers the magnitude of the producer surplus given the now exogenous level of expenditures that were made over history (January 2003 through December 2018). In our analysis, we analyze the effects of a historically fixed level of promotion expenditures given different assumptions on the level of export supply responsiveness to price. Thus, in our analysis, the expenditures do not change as the export supply elasticity changes because the expenditure levels are fixed (exogenous) historically in the analysis. 


\section{Effects of NSC pelagic export promotion under Norwegian fishery management systems}

\subsection{Econometric analysis of promotion effects on Norwegian herring and mackerel export demand}

Equation 1 for herring and mackerel was specified and econometrically estimated over January 2003 through December 2018 (192 monthly observations) as:

$$
\mathrm{NPXD}_{\mathrm{jt}}=\mathrm{f}\left(\frac{\mathrm{NPP}_{\mathrm{jt}}}{\mathrm{FAOPI}_{\mathrm{t}}} \mathrm{ER}_{\mathrm{jt}}, \frac{\mathrm{MGDP}_{\mathrm{jt}}}{\mathrm{MCPI}_{\mathrm{jt}}} \mathrm{ER}_{\mathrm{jt}}, \frac{\mathrm{EXP}_{\mathrm{jt}}}{\mathrm{MCP}_{\mathrm{jt}}} \mathrm{ER}_{\mathrm{jt}}, \operatorname{PDL}\left(\mathrm{G}_{\mathrm{jt}-\mathrm{n}}\right), \mathrm{NPXD}_{\mathrm{jt}-1} \mathrm{SEAS}_{\mathrm{jt}}, \mathrm{I}_{\mathrm{jt}}\right)
$$

where, for each pelagic species j (=herring, mackerel), NPXD = monthly Norwegian export volume; NPP $=$ monthly nominal Norwegian export price; FAOPI $=$ the FAO pelagic price index; ER $=$ monthly tradeweighted index of the NOK exchange rate against the top 10 importing countries constructed as explained earlier; MGDP = monthly trade-weighted nominal GDP of the top 10 importing countries; MCPI = monthly trade-weighted consumer price index of those same countries; $\operatorname{PDL}\left(\mathrm{G}_{\mathrm{jt-n}}\right)=$ polynomial distributed lag model of the goodwill stock of the Norwegian export promotion expenditures $(G)$ over months $t, \ldots t-n$, where $\mathrm{G}_{\mathrm{jt}-\mathrm{n}}=\left(\frac{\mathrm{EXP}_{\mathrm{j} t-\mathrm{n}}}{\mathrm{MCP}_{\mathrm{j} t-\mathrm{n}}} \mathrm{ER}_{\mathrm{jt}-\mathrm{n}}\right), \mathrm{EXP}$ is the seasonally adjusted monthly nominal NSC promotion expenditures, and $\mathrm{n}$ is the lag length determined as discussed earlier; SEAS = seasonal monthly indicator variable with July as the base month; $\mathrm{I}=$ indicator variables for events affecting herring and mackerel markets; and $\mathrm{t}=$ time period (month). Equation 8 was estimated in double log form using OLS using monthly data over January 2003 through December 2018 and yielded estimates of price, income, and NSC promotion elasticities for Norwegian herring and mackerel. We assume that the elasticities are constant over this period. Model selection criteria determined appropriate equation specifications for Equation 8 for each pelagic species.

\section{- Norwegian herring export demand and NSC promotion}

The selected equation for Norwegian herring export demand explains $84.9 \%$ (adjusted $\mathrm{R}^{2}$ ) of the variation in that demand over the study period (Table 1). The signs and magnitudes of all estimated coefficients are consistent with prior expectations. The within-sample mean absolute percentage error (MAPE) is $21.4 \%$. The Breusch-Godfrey LM test (Breusch, 1978; Godfrey, 1978) indicated the absence of serial correlation. ARCH tests, up to four lags of squared residuals, indicated the absence of any heteroscedasticity over time, further corroborating that the model was appropriately specified. Using a Wu-Hausman test for price endogeneity (Hausman, 1978; Wu, 1973) in which instrumental variable (IV) estimates (2SLS estimates) are compared to OLS estimates, the hypothesis of the exogeneity of price was not rejected. ${ }^{4}$ So, price endogeneity is not a source of bias in the econometric analysis. As is the case with most export demand promotion evaluation studies, promotion expenditures are predetermined in the model (see Williams et al., 2016).

The price and income elasticities of Norwegian herring export demand were estimated to be -0.58 and 0.24 , respectively (Table 1). These estimates compare favorably to those reported for Norwegian whitefish export demand (-0.31 and 0.25, respectively) (Williams and Capps, 2020b). Seasonality also was evident according to the econometric results. Several qualitative events also were found to be drivers of Norwegian herring exports, including: (1) the Ukraine crisis during selected months of 2014 through 2018; (2) the increase in the Iceland and the Faroe Islands catch particularly in April 2006, September 2012, February 2013, and October 2013; (3) the global financial crisis in 2007 and 2008; (4) the economic recession in 2008 and 2009; (5) the Russian import ban in August 2014; and (6) the decrease in the herring quota and catch beginning in August 2011. The estimated coefficient of the lagged dependent variable (0.48) is statistically significant indicating that habit (persistence) or inertia is a key driver of Norwegian herring export demand as well.

\footnotetext{
${ }^{4}$ In general, econometric analyses use data with unit roots. Augmented Dickey-Fuller (ADF) tests, however, indicated that the continuous predetermined variables are stationary in this analysis.
} 
Table 1. Econometric estimation results for Norwegian herring export demand. ${ }^{\mathrm{a}}$

\begin{tabular}{|c|c|c|c|c|}
\hline Variables (in natural logs except indicator variables) & $\begin{array}{l}\text { Parameter } \\
\text { estimate }\end{array}$ & $\begin{array}{l}\text { Standard } \\
\text { error }\end{array}$ & $t$-value & $P$-value \\
\hline Intercept & 3.6442 & 0.8871 & 4.1082 & 0.0001 \\
\hline \multicolumn{5}{|l|}{ Seasonality } \\
\hline$@ \operatorname{SEAS}(1)$ & 0.9242 & 0.1029 & 8.9839 & 0.0000 \\
\hline @SEAS(2) & 1.0410 & 0.1049 & 9.9250 & 0.0000 \\
\hline$@ \operatorname{SEAS}(3)$ & 0.3469 & 0.1023 & 3.3907 & 0.0000 \\
\hline @SEAS(4) & 0.1018 & 0.0993 & 1.0246 & 0.3070 \\
\hline$@ \operatorname{SEAS}(5)$ & 0.2932 & 0.1025 & 2.8608 & 0.0048 \\
\hline$@ \operatorname{SEAS}(6)$ & 0.9650 & 0.1033 & 9.3423 & 0.0000 \\
\hline @ SEAS(8) & 0.1291 & 0.1081 & 1.1941 & 0.0000 \\
\hline$@ \operatorname{SEAS}(9)$ & 0.7645 & 0.1089 & 7.0199 & 0.0000 \\
\hline @SEAS(10) & 1.4248 & 0.1046 & 13.6181 & 0.0000 \\
\hline @SEAS(11) & 1.2065 & 0.0993 & 12.1536 & 0.0000 \\
\hline @ $\operatorname{SEAS}(12)$ & 0.5797 & 0.1046 & 5.5436 & 0.0000 \\
\hline \multicolumn{5}{|l|}{ Economic factors } \\
\hline $\begin{array}{l}\text { Norwegian herring export price/FAO pelagic price index } \\
\text { (exchange-rate-adjusted) }\end{array}$ & -0.5769 & 0.0956 & -6.0350 & 0.0000 \\
\hline GDP of importing countries (real, exchange-rate-adjusted) & 0.2361 & 0.1526 & 1.5476 & 0.1236 \\
\hline Inertia (lagged dependent variable) & 0.4822 & 0.0470 & 10.2597 & 0.0000 \\
\hline \multicolumn{5}{|l|}{ Qualitative factors } \\
\hline Ukraine crisis & -0.8481 & 0.1092 & -7.7695 & 0.0000 \\
\hline Iceland/Faroe Islands catch & -0.7908 & 0.1464 & -5.4028 & 0.0000 \\
\hline Beginning of the Russian import ban & -0.6915 & 0.3045 & -2.2706 & 0.0244 \\
\hline Financial meltdown & -0.9157 & 0.2923 & -3.1329 & 0.0020 \\
\hline Recession & -1.0052 & 0.2900 & -3.4660 & 0.0007 \\
\hline Reduction in herring quota and catch beginning August 2011 & -0.6935 & 0.2888 & -2.4014 & 0.0174 \\
\hline \multicolumn{5}{|l|}{ Goodwill variable of NSC promotion herring expenditures ${ }^{\mathrm{a}}$} \\
\hline NSC promotion expenditures in current period & 0.0260 & 0.0110 & 2.3701 & 0.0189 \\
\hline NSC promotion expenditures lagged one period & 0.0260 & 0.0110 & 2.3701 & 0.0189 \\
\hline Sum of lags & 0.0519 & 0.0219 & 2.3701 & 0.0189 \\
\hline \multicolumn{5}{|l|}{ Regression statistics: Adj. $\mathrm{R}^{2}=0.8490, \mathrm{DW}=2.01$} \\
\hline
\end{tabular}

Importantly, the results provide evidence of a statistically significant, positive effect of NSC promotion on Norwegian herring export demand over the years (Table 1). To account for the lagged effect of promotion, the analysis considered polynomial distributed lags of orders 2 and 3 with and without endpoint restrictions for lag lengths of orders 1 through 12. The lag specification minimizing the model selection criteria was a second-degree polynomial with endpoint constraints and a lag of one month. In other words, NSC herring export demand in a particular month is impacted by promotion expenditures in not only that month but also by expenditures in the previous month. The short-run (contemporaneous) and long-run (cumulative) elasticities of NSC export promotion are 0.026 and 0.052 , respectively. ${ }^{5}$ These elasticities are consistent

\footnotetext{
5 This long-run elasticity is a static measure of promotion impact and assumes that all else is held constant. As such, if the Norwegian Seafood Council were to increase promotion expenditures by $10 \%$, then Norwegian exports of herring would rise by $0.52 \%$. Given the presence of the lag in the dependent variable, a dynamic long-run elasticity also can be calculated by dividing the static long-run promotion elasticity by one minus the estimated coefficient of the lagged dependent variable. The result is a dynamic long-run elasticity of 0.100 .
} 
with the range of elasticities reported for U.S. agricultural export promotion programs (Williams et al., 2016). They are also consistent with elasticities reported for NSC whitefish export promotion ( 0.024 in the short-run and 0.079 over the long-run) (Williams and Capps, 2020b). The long-run herring export promotion elasticity also is consistent with the range of corresponding estimates reported for NSC salmon promotion (0.0133 (Xie et al., 2009) to 0.059 (Myrland and Kinnucan, 2000) but lower than reported for NSC seafood promotion (0.1558 (Williams and Capps, 2020c)).

\section{- Norwegian mackerel export demand and NSC promotion}

The selected Norwegian mackerel export demand equation explains 91.0\% (adjusted $\mathrm{R}^{2}$ ) of the variation in that demand over time (Table 2). The signs and magnitudes of all estimated coefficients are consistent with prior expectations and the within-sample MAPE is $24.7 \%$. The Breusch-Godfrey LM test indicated the absence of serial correlation while ARCH tests indicated the absence of heteroscedasticity in the residuals in this equation. Similar to the export demand model for Norwegian herring, using a Wu-Hausman test for price endogeneity (Hausman, 1978; Wu, 1973) in which instrumental variable (IV) estimates (2SLS estimates) are compared to OLS estimates, the hypothesis of the exogeneity of price was not rejected. So, once again price endogeneity is not a source of bias in the econometric analysis. Further, like many studies of domestic and export demand promotion, promotion expenditures are predetermined in the model. Thus, there is no need to account for possible bias attributed to the endogeneity of promotion.

The price and income elasticities of Norwegian mackerel export demand were estimated to be -0.29 and 0.59 , respectively indicating that Norwegian mackerel export demand is somewhat more price inelastic but less income inelastic than Norwegian herring export demand (Table 2). Similar to herring, seasonality in Norwegian mackerel exports was evident. Several qualitative events also were found to be drivers of Norwegian mackerel export demand, including: (1) the jump in Iceland's and the Faroe Islands' mackerel supplies in September 2007 and June 2010, respectively; (2) a South Korean ban on mackerel imports from Japan in August and September 2010; and (3) a rise in the Japanese mackerel catch particularly in September 2006. The estimated coefficient of the lagged dependent variable (0.29) is statistically significant suggesting habitual behavior affecting Norwegian mackerel exports although the low level of the coefficient indicates a relatively quicker month to month response to changes in market conditions compared to herring.

As with herring, NSC mackerel promotion expenditures were found to have a positive and statistically significant effect over the study period on Norwegian mackerel export demand. Employing the same model selection process used for herring export demand, the specification that minimized the selection criteria was a second-degree polynomial with endpoint constraints and a lag of eight months. The estimated short-run and long-run elasticities of NSC mackerel export promotion were 0.004 and 0.081 , respectively. ${ }^{6}$ Although the estimated long-run promotion elasticities for herring and mackerel are similar, NSC promotion tends to have a much more immediate effect on herring export demand while taking much longer to realize its full effects on mackerel export demand.

\subsection{Counterfactual (simulation) analysis results}

The econometric results were used to simulate the effects of NSC herring and mackerel export promotion following the procedures outlined previously. The simulation analyses assume that Norwegian herring and mackerel export supplies were highly but not totally restricted by their respective fishery management rules over time defined as a long-run export supply elasticity of 0.5 . The simulated differences between the

\footnotetext{
${ }^{6}$ This long-run elasticity is a static measure of promotion impact and assumes that all else is held constant. As such, if the Norwegian Seafood Council were to increase promotion expenditures by $10 \%$, then Norwegian exports of mackerel would rise by $0.81 \%$. Given the presence of the lag in the dependent variable, a dynamic long-run elasticity also can be calculated by dividing the static long-run promotion elasticity by one minus the estimated coefficient of the lagged dependent variable. The result is a dynamic long-run elasticity of 0.114 .
} 
Table 2. Econometric estimation results for Norwegian mackerel export demand. ${ }^{a}$

\begin{tabular}{|c|c|c|c|c|}
\hline Variables (in natural logs except indicator variables) & $\begin{array}{l}\text { Parameter } \\
\text { estimate }\end{array}$ & $\begin{array}{l}\text { Standard } \\
\text { error }\end{array}$ & $t$-value & $P$-value \\
\hline Intercept & 6.8674 & 1.1777 & 5.8310 & 0.0000 \\
\hline \multicolumn{5}{|l|}{ Seasonality } \\
\hline @ $\operatorname{SEAS}(1)$ & 1.4834 & 0.1431 & 10.3651 & 0.0000 \\
\hline @SEAS(2) & 1.4133 & 0.1535 & 9.2095 & 0.0000 \\
\hline$@ \operatorname{SEAS}(3)$ & 0.6496 & 0.6496 & 4.3544 & 0.0000 \\
\hline @SEAS(4) & 0.4127 & 0.1283 & 3.2170 & 0.0016 \\
\hline$@$ SEAS(5) & 0.4219 & 0.1230 & 3.4301 & 0.0008 \\
\hline$@ \operatorname{SEAS}(6)$ & 0.5199 & 0.1245 & 4.1747 & 0.0000 \\
\hline$@ \operatorname{SEAS}(8)$ & 0.4750 & 0.1280 & 3.7122 & 0.0003 \\
\hline$@ \operatorname{SEAS}(9)$ & 2.3943 & 0.1278 & 18.7328 & 0.0000 \\
\hline @SEAS(10) & 2.7821 & 0.1741 & 15.9826 & 0.0000 \\
\hline @SEAS(11) & 1.6102 & 0.2117 & 7.6048 & 0.0000 \\
\hline @ $\operatorname{SEAS}(12)$ & 0.8979 & 0.1741 & 5.1563 & 0.0000 \\
\hline \multicolumn{5}{|l|}{ Economic factors } \\
\hline $\begin{array}{l}\text { Norwegian mackerel export price/FAO pelagic price index } \\
\text { (exchange-rate-adjusted) }\end{array}$ & -0.2893 & 0.1052 & -2.7507 & 0.0066 \\
\hline GDP of importing countries (real, exchange-rate-adjusted) & 0.5903 & 0.1894 & 3.1162 & 0.0022 \\
\hline Inertia (lagged dependent variable) & 0.2867 & 0.0624 & 4.5915 & 0.0000 \\
\hline \multicolumn{5}{|l|}{ Qualitative factors } \\
\hline South Korea stop importing mackerel from Japan & 1.0844 & 0.2476 & 4.3797 & 0.0000 \\
\hline Jump in the supply of mackerel from Iceland & -1.3096 & 0.3478 & -3.7661 & 0.0002 \\
\hline Jump in the supply of mackerel from the Faroe Islands & -1.1009 & 0.3513 & -3.1335 & 0.0020 \\
\hline Rise in the catch of mackerel from Japan & -0.9130 & 0.3552 & -2.5707 & 0.0110 \\
\hline \multicolumn{5}{|l|}{ Goodwill variable of NSC promotion mackerel expenditures $\mathrm{a}^{\mathrm{a}}$} \\
\hline NSC promotion expenditures in current period & 0.0044 & 0.0016 & 2.7167 & 0.0073 \\
\hline NSC promotion expenditures lagged one period & 0.0079 & 0.0029 & 2.7167 & 0.0073 \\
\hline NSC promotion expenditures lagged two periods & 0.0103 & 0.0038 & 2.7167 & 0.0073 \\
\hline NSC promotion expenditures lagged three periods & 0.0118 & 0.0043 & 2.7167 & 0.0073 \\
\hline NSC promotion expenditures lagged four periods & 0.0123 & 0.0045 & 2.7167 & 0.0073 \\
\hline NSC promotion expenditures lagged five periods & 0.0118 & 0.0043 & 2.7167 & 0.0073 \\
\hline NSC promotion expenditures lagged six periods & 0.0103 & 0.0038 & 2.7167 & 0.0073 \\
\hline NSC promotion expenditures lagged seven periods & 0.0079 & 0.0029 & 2.7167 & 0.0073 \\
\hline NSC promotion expenditures lagged eight periods & 0.0044 & 0.0016 & 2.7167 & 0.0073 \\
\hline Sum of lags & 0.0811 & 0.0298 & 2.7167 & 0.0073 \\
\hline \multicolumn{5}{|l|}{ Regression statistics: Adj. $\mathrm{R}^{2}=0.9099, \mathrm{DW}=1.77$} \\
\hline
\end{tabular}

respective 'with' and 'without' scenarios are referred to as the 'lift' provided by NSC promotion. The 'lift' is the addition to total export volume, export revenue, or other industry measures generated by promotion. In other words, 'lift' is the contribution of promotion to the level of some industry measure in a given period or over time. Additional simulations for each pelagic species were also conducted for comparison purposes with alternative export supply elasticities. 
The use of the simulation analysis is standard practice in the literature dealing with evaluation of the effectiveness of promotion programs. In Kinnucan and Gong (2014), the change in producer surplus, a measure of the welfare effect associated with promotion, is approximated as a function of: (1) the ownprice elasticity in the export market; (2) the export supply elasticity; (3) the export promotion elasticity; (4) the price elasticity of supply for domestic production; (5) the proportionate change in export price; (6) the proportionate change in export supply; and (7) the proportionate change in 'goodwill.' The term 'goodwill' used by Nerlove and Arrow (1962) is a stock variable associated with advertising. The amount of advertising in the current period is a function of the current level of goodwill which in turn is a function of current and past advertising outlays. In our analysis, we explicitly account for all these variables in as structural model in which the parameters are econometrically estimated rather than assumed except for the price elasticity of export supply which is close to zero given that the production is limited by quotas. Consequently, the simulation analysis is tantamount at least in theory to that of Kinnucan and Gong (2014) except that the model parameters are econometrically estimated not counting the export supply elasticities. Importantly, as stated previously, because no other exogenous variables in the model (e.g. levels of inflation, exchange rates, income levels, etc.) other than the NSC promotion expenditures are allowed to change in either scenario, the use of simulation analysis effectively isolates the effects of the NSC promotion expenditures on aggregate Norwegian seafood export volume, value, and price.

\section{- NSC herring promotion counterfactual simulation}

The simulation analysis indicates that NSC herring export promotion generated an average annual lift in the Norwegian herring export volume over the period of analysis of only $1.6 \%$ but a $4.0 \%$ lift in the Norwegian herring export price (second column of Table 3). Together, the lift in the herring export price and volume resulted in a 5.2\% lift in the Norwegian herring export revenue and a 7\% lift in the Norwegian herring industry profit. Given that annual Norwegian herring exports were consistently below the annual catch levels and TAC limits over the 2003 to 2018 period of analysis, NSC promotion had the effect of diverting some of the Norwegian herring catch from other uses such as the domestic Norwegian market to exports or even pushing the catch level toward the catch limits.

In contrast, if the Norwegian herring fishery management system totally limited Norwegian herring export supplies over the study period (first column of Table 3), NSC herring export promotion expenditures would have been unsuccessful in achieving any lift in the export volume. Instead, the additional demand pressure generated by NSC promotion would have translated into a herring export price lift of $8.2 \%$. Given the inelasticity of the herring export demand (-0.577), NSC promotion would have lifted Norwegian herring export revenue and industry profit by 6.6 and $13.2 \%$, respectively. On the other hand, the higher the export supply elasticity (i.e. the less export-limiting the Norwegian herring management system becomes), the greater the effect of NSC promotion on herring export volume but the smaller the effect on the export price (last 3 columns of Table 3 ) and, thus, the smaller the gain to stakeholders in export revenue and profit.

For mackerel, the simulation results indicate that NSC export promotion lifted export volume and price by 3.6 and $9 \%$, respectively over the study period (second column of Table 4 ). The consequence was a lift in Norwegian mackerel export revenue and industry profit of 10.8 and $14.8 \%$, respectively. Over that period, annual mackerel exports were basically restricted by the annual catch level rather than the TAC limit given that exports accounted for nearly all of the catch each year and that the catch averaged about $130 \%$ of the TAC limit over the same period. Thus, the lift in Norwegian mackerel exports achieved by the NSC promotion program basically incentivized a small addition to the Norwegian mackerel catch to feed the demand created by the promotion (3.6\%). The primary effect of the NSC mackerel promotion, however, was to pressure the Norwegian mackerel export price upward by nearly $11 \%$. 
Table 3. Lift ${ }^{\mathrm{a}}$ from NSC herring export promotion with fishery management limitations on export supplies, 2003-2018.

\begin{tabular}{|c|c|c|c|c|c|}
\hline \multirow[b]{3}{*}{ Lift to: } & \multicolumn{5}{|c|}{ Alternative levels of export supply limitation ${ }^{b}$} \\
\hline & \multirow{2}{*}{$\begin{array}{l}\text { Total limitation } \\
\text { (0) }\end{array}$} & \multirow{2}{*}{$\begin{array}{l}\text { High limitation } \\
0(0.5)\end{array}$} & \multicolumn{3}{|c|}{ Progressively less limitation } \\
\hline & & & $(\mathbf{1 . 0 )}$ & (1.5) & (2.0) \\
\hline \multicolumn{6}{|l|}{ Exports (tons) } \\
\hline - All years & 0 & 119,170 & 162,768 & 185,374 & 199,208 \\
\hline - Average monthly & 0 & 624 & 852 & 971 & 1,043 \\
\hline - Percentage & 0 & 1.6 & 2.3 & 2.6 & 2.8 \\
\hline \multicolumn{6}{|c|}{ Export revenue (NOK million) } \\
\hline - All years & 3,405 & 2,665 & 2,409 & 2,280 & 2,201 \\
\hline - Average monthly & 17.8 & 14.0 & 12.6 & 11.9 & 11.5 \\
\hline - Percentage & 6.6 & 5.2 & 4.7 & 4.4 & 4.3 \\
\hline \multicolumn{6}{|c|}{ Industry profit (NOK million) } \\
\hline - All years & 3,405 & 1,807 & 1,230 & 932 & 750 \\
\hline - Average monthly & 17.8 & 9.5 & 6.4 & 4.9 & 3.9 \\
\hline - Percentage & 13.2 & 7.0 & 4.8 & 3.6 & 2.9 \\
\hline \multicolumn{6}{|c|}{ Export price (NOK/kg) } \\
\hline - Average monthly & 0.57 & 0.31 & 0.21 & 0.16 & 0.13 \\
\hline - Percentage & 8.2 & 4.0 & 2.7 & 2.0 & 1.6 \\
\hline
\end{tabular}

Table 4. Lift ${ }^{\mathrm{a}}$ from NSC mackerel export promotion given fishery management limitations on export supplies, 2003-2018.

\begin{tabular}{|c|c|c|c|c|c|}
\hline \multirow[b]{3}{*}{ Lift to: } & \multicolumn{5}{|c|}{ Alternative levels of export supply limitation ${ }^{\text {b }}$} \\
\hline & \multirow{2}{*}{$\begin{array}{l}\text { Total limitation } \\
\text { (0) }\end{array}$} & \multirow{2}{*}{$\begin{array}{l}\text { High limitation } \\
0(0.5)\end{array}$} & \multicolumn{3}{|c|}{ Progressively less limitation } \\
\hline & & & (1.0) & (1.5) & (2.0) \\
\hline \multicolumn{6}{|l|}{ Exports (metric tons) } \\
\hline - All years & 0 & 140,250 & 171,717 & 185,598 & 193,415 \\
\hline - Average monthly & 0 & 762 & 933 & 1,009 & 1,051 \\
\hline - Percentage & 0 & 3.6 & 4.5 & 4.9 & 5.1 \\
\hline \multicolumn{6}{|c|}{ Export revenue (NOK million) } \\
\hline - All years & 9,552 & 5,007 & 4,052 & 3,639 & 3,408 \\
\hline - Average monthly & 51.9 & 27.2 & 22.0 & 19.8 & 18.5 \\
\hline - Percentage & 20.5 & 10.8 & 8.7 & 7.8 & 7.3 \\
\hline \multicolumn{6}{|c|}{ Industry profit (NOK million) } \\
\hline - All years & 9,552 & 3,433 & 2,092 & 1,505 & 1,175 \\
\hline - Average monthly & 51.9 & 18.7 & 11.4 & 8.2 & 6.4 \\
\hline - Percentage & 41.0 & 14.8 & 9.0 & 6.5 & 5.0 \\
\hline \multicolumn{6}{|c|}{ Export price $(\mathrm{NOK} / \mathrm{kg})$} \\
\hline - Average monthly & 2.71 & 0.99 & 0.61 & 0.44 & 0.34 \\
\hline - Percentage & 28.9 & 9.0 & 5.3 & 3.8 & 2.9 \\
\hline
\end{tabular}


If the Norwegian mackerel fishery management system had completely restricted the availability of Norwegian mackerel export supplies (totally inelastic export supply), NSC export promotion would have enhanced the Norwegian mackerel export price by as much as $28.5 \%$ with no effect on the export volume (first column of Table 4). The resulting lift in industry revenue and profit would have been substantial at 20.5 and $41 \%$, respectively. As is the case for herring, a progressively less export-supply-limiting effect of the Norwegian mackerel fishery management system would have allowed NSC export promotion to generate more mackerel exports but at an increasingly lower price (columns 3, 4, and 5 in Table 4). The consequence would be an increasingly smaller effect on Norwegian mackerel export revenue and industry profit. These results differ substantially from those for herring primarily because of the much lower estimated price elasticity of Norwegian mackerel export demand (-0.289 compared to -0.577 for herring) and the much higher long-run export promotion elasticity for mackerel ( 0.081 compared to 0.052 for herring). As a result, the increase in export revenue and industry profit also was larger for mackerel than for herring at every possible level of export supply elasticity. The relatively lower estimated promotion elasticity for herring than for mackerel likely relates to the loss of the primary market for Norwegian herring (Russia) beginning in 2014, the reductions in the herring quota, catch, and, therefore exports, beginning in 2009, the associated reduction in funds to promote herring exports, and the need to divert the lower herring export promotion funds to activities and markets where the return on investment was relatively lower.

\subsection{Benefit-cost analysis of NSC herring and mackerel export promotion}

The econometric and simulation results provide evidence that NSC export promotion increased Norwegian herring and mackerel export volumes, revenues, prices and industry profits over the study period. Perhaps of more importance is whether those gains were sufficient to more than cover the costs of the promotion to stakeholders. Using the simulation results corresponding to a reasonably high level of fishery management system limitation of the export supplies of each pelagic fish (export supply elasticities of 0.5 ) and Equations 5 through 7, BCRs for NSC herring and mackerel export promotion were calculated over January 2003 through December 2018. ${ }^{7}$ A BCR greater than 1 means that the NSC promotion generated a gain to stakeholders because the benefit generated is greater than the cost of the program.

The NBCRs for NSC herring and mackerel export promotion over the period of analysis were calculated to be 8.9 and 19.0, respectively (Table 5). Thus, for every krone of export promotion expenditure, the additional export revenue earned by Norwegian herring and mackerel stakeholders, net of promotion expenditures, was 8.9 kroner and 19.0 kroner per kroner spent by the NSC on the respective export promotion programs.

The SBCRs for NSC herring and mackerel export promotion over the study period are calculated to be 5.7 and 12.7, respectively (Table 5). In other words, NSC herring and mackerel export promotion generated a net addition to the profit of the Norwegian herring and mackerel industries and to Norwegian economic welfare of 5.7 kroner and 12.7 kroner per krone of export promotion spent by the NSC on herring and mackerel export promotion, respectively. The SBCRs are smaller than the NBCRs because additional economic costs associated with higher levels of exports have been subtracted from the additional export revenue generated.

The BCRs for NSC herring export promotion are in line with those reported for NSC export promotion for salmon (2.56 to 9.53) as well for skrei and fresh cod (1.02 and 4.56, respectively) and for all whitefish (5.90) (Williams and Capps, 2020b). The NSC mackerel export promotion BCR is higher but in line with the BCR of 12.6 for NSC promotion of all seafood (Williams and Capps, 2020c) as well as with the 10.8 average BCR over all U.S. agricultural commodity export promotion programs (Williams et al., 2016) and the BCR for the USDA agricultural export market development program of 13.9 (Williams et al., 2016).

\footnotetext{
${ }^{7}$ Comparison BCRs could be calculated based on the simulation results using the comparison export supply elasticities. Such ex-post calculations would assume that the expenditure levels $\left(\mathrm{E}_{\mathrm{j}}\right)$ used in the denominator of each BCR calculated is historically fixed (exogenous) and, therefore, would not change given changes in the export supply elasticity (Williams and Capps, 2020a). If this paper was concerned with calculating the optimal expenditure levels, the export supply elasticity assumed would have no effects on the BCR calculations (Kinnucan and Myrland, 2000).
} 
Table 5. Benefit-cost ratios (BCRs) for NSC herring export promotion assuming a reasonably high level of fishery management system limitations of Norwegian herring and mackerel export supplies ${ }^{\mathrm{a}}$, for the period 2003-2018.

\begin{tabular}{lll}
\hline & $\begin{array}{l}\text { NSC herring } \\
\text { promotion }\end{array}$ & $\begin{array}{l}\text { NSC mackerel } \\
\text { promotion }\end{array}$ \\
\hline Additional export revenue (NOK million) & 2,665 & 5,007 \\
Additional industry profit (NOK million) & 1,807 & 3,433 \\
NSC promotion investment (NOK million) & 269.6 & 249.9 \\
Gross export revenue BCR (GBCR) (NOK added/NOK spent) & 9.9 & 20.0 \\
Net export revenue BCR (NBCR) (NOK added/NOK spent) & 8.9 & 19.0 \\
Net export surplus (profit) BCR (SBCR) (NOK added/NOK spent) & 5.7 & 12.7 \\
\hline
\end{tabular}

${ }^{a}$ Export supply elasticity for both herring and mackerel are assumed to be 0.5 .

\section{Conclusions and implications}

The Norwegian fishery management system and the Norwegian pelagic export promotion program seem to be in direct conflict. Norway has established fishery management system rules which limit catch levels in an effort to promote the long-run economic and biologic sustainability of Norwegian fisheries. At the same time, however, the Norwegian government operates an aggressive program to promote the demand for herring and mackerel in markets all over the world, incentivizing growth in Norway's herring and mackerel exports and, thus, their catch levels to feed the demand created by the promotion. The research presented here, however, demonstrates that effective limits on the availability of Norwegian herring and mackerel for export by their respective fishery management systems work to maximize the effectiveness of NSC herring and mackerel export promotion in boosting the profitability of their respective industries. The reason is that the export demand for each Norwegian pelagic species is estimated to be inelastic. Thus, effectively constraining increases in the export levels of the two pelagic species from increased foreign demand pressure created by NSC export promotion translates into higher prices for Norwegian exports of each species and, therefore, higher export revenues and industry profit.

In essence, the effectiveness of the NSC export promoting program in creating benefits for the Norwegian herring and mackerel industries depends on the effectiveness of the corresponding fishery management system in limiting the catch and, therefore, the supplies of the respective pelagic fish available for export. A failure of fishery management systems to control catch and export levels thus compromises the NSC export promotion efforts and leads to potentially large losses in economic rent that the promotion might otherwise have been able to generate for the Norwegian pelagic fish industry.

Assuming highly (but not perfectly) effective limits on herring and mackerel exports arising from their respective fishery management systems (corresponding to export supply elasticities of 0.5 ) over the 2003 to 2018 period of analysis, NSC export promotion contributed 5.2 and $10.8 \%$ to the export revenue and 7 and $14.8 \%$ to the profit of the Norwegian herring and mackerel industries, respectively. To the extent that catch levels and, therefore, supplies available for export are not well controlled by the corresponding fishery management systems, the export revenue and industry profit gains from NSC export promotion programs could be seriously eroded. This case might apply to the NSC mackerel promotion given that catch levels exceeded the limits imposed by the Norwegian mackerel fishery management system by an average of $30 \%$ over the study period and that Norway exports almost all of its mackerel catch. Also, to the extent that catch levels and, thus, exports are below limits prescribed by fishery management systems for whatever reason or when exports are much below catch levels, NSC export promotion may have more effect on export volume and less on price, again leading to some erosion in the export revenue and industry profit gains from the promotion. This case could well define the NSC herring export promotion program given that Norwegian herring exports averaged $36 \%$ below catch levels over the study period. 
The estimated average industry profit BCRs for herring and mackerel of 5.7 and 12.7, respectively, indicate that NSC promotion programs were profitable investments for both industries over 2003 to 2018 in terms of kroner earned per krone invested in promotion. The relatively lower BCR for herring export promotion likely relates to the loss of the primary market for Norwegian herring beginning in 2014 (Russia), the reduction in the Norwegian herring quota, catch, and, therefore, exports after 2009, the associated reduction in funds to promote herring exports, and the need to re-direct the lower herring export promotion funds in recent years to activities and markets where the return on investment was relatively lower.

\section{Funding}

This work was funded by the Norwegian Seafood Council, Tromsø, Norway.

\section{Acknowledgements}

We gratefully acknowledge the Norwegian Seafood Council for their assistance in understanding the Norwegian pelagic fisheries and industry and in providing us access to their financial, export, and other data. We are particularly grateful to Dr. Ingrid Kristine Pettersen, Seafood Analyst, Market Insight, for her assistance as well as many others on the NSC Staff and Board who freely shared data and information with us. Sigbjorn Tveterås provided useful insights and a review of existing economic research on pelagic fish. Nevertheless, the findings and conclusions are those of the authors alone and do not necessarily represent the views of the Norwegian Seafood Council or of Texas A\&M University.

\section{References}

ABPmer. 2018. Building resilience of fisheries governance in the North East Atlantic, final report. ABP Report No. R.2924. A report produced by ABPmer for the Environmental Defense Fund. Available at: https://www.edf.org/sites/default/files/documents/building-resilience-fisheries-governance.pdf

Anderson, B., T.K. Lien, R. Tveteras and S. Tveteras. 2009. The Russian seafood revolution: shifting consumption towards aquaculture products. Aquaculture Economics and Management 13(3): 191-212.

Biorndal, T. and J.M. Conrad. 1987. The dynamics of an open access fishery. Canadian Journal of Economics 20(1): 74-85.

Breusch, T.S. 1978. Testing for autocorrelation in dynamic linear models. Australian Economic Papers 17(31): 334-355.

Chang, H.S. and H.W. Kinnucan. 1991. Economic effects of an advertising excise tax. Agribusiness:an International Journal 7(2): 165-171.

Food and Agriculture Organization. 1995. Code of conduct for responsible fisheries. Food and Agriculture Organization, Rome, Italy. Available at: http://www.fao.org/fishery/code/en

Forker, O.D. and R.W. Ward. 1993. Commodity advertising: the economics and measurement of generic programs. Lexington Books, New York, NY, USA.

Ghosh, S. and G.W. Williams. 2016. Generic advertising of U.S. lamb. International Journal of Food and Agribusiness Marketing 28(4): 373-393.

Godfrey, L.G. 1978. Testing against autoregressive and moving average error models when the regressors include lagged dependent variables. Econometrics 46(6): 1293-1301.

Gordon, D.V. and R. Hannesson. 2015. The Norwegian winter herring fishery: a story of technological progress and stock collapse. Land Economics 91(2): 362-385.

Gullestad, P., A. Aglen, A. Biordal, G. Blom., S. Johansen, J. Krog, O.A. Misund and I. Rottingen. 2014. Changing attitudes 1970-2012: evolution of the Norwegian management framework to prevent overfishing and to secure long-term sustainability. ICES Journal of Marine Science 71: 173-182.

Hausman, J.A. 1978. Specification tests in econometrics. Econometrica 46(6): 1251-1271. 
Hoggarth, D.D., S. Abeyasekera, R.I. Arthur, J.R. Beddington, R.W. Burn, A.S. Halls, G.P. Kirkwood, M. McAllister, P. Medley, C.C. Mees, G.B. Parkes, G.M. Pilling, R.C. Wakeford and R.L. Welcomme. 2006. Stock assessment for fishery management. A framework guide to the stock assessment tools of the Fisheries Management Science Programme (FMSP). FAO Fisheries Technical Paper. No. 487. FAO, Rome, Italy, $261 \mathrm{pp}$.

International Monetary Fund (IMF). 2019. International financial statistics. IMF, Washington, DC, USA. Available at: http://data.imf.org/?sk=388DFA60-1D26-4ADE-B505-A05A558D9A42

Kaiser, H.M. 2015. Economic analysis of Norwegian Seafood Council salmon export promotion to the European Union. Unpublished report to the Norwegian Seafood Council. Norwegian Seafood Council, Tromsø, Norway.

Kinnucan, H.W. and C.R. Clary. 1995. Brand versus generic advertising: a conceptual framework with an application to cheese. Agribusiness: an International Journal 11(4): 355-369.

Kinnucan, H.W. and H. Cai. 2011. A benefit-cost analysis of U.S. agricultural trade promotion. American Journal of Agricultural Economics 93(1): 194-208.

Kinnucan, H.W. and L. Gong. 2014. Goodwill and export promotion dynamics. Journal of Agricultural and Applied Economics 46: 73-89.

Kinnucan, H.W. and O. Myrland. 2000. Optimal advertising levies with application to the Norway-EU salmon agreement. European Review of Agricultural Economics 27: 39-57.

Kinnucan, H.W. and O. Myrland. 2001. A note on measuring returns to nonprice export promotion. Agribusiness: an International Journal 17(3): 423-433.

Kinnucan, H.W. and O. Myrland. 2002. Relative impact of the Norway-EU salmon agreement: a midterm assessment. Journal of Agricultural Economics 53(2): 195-219.

Kinnucan, H.W. and O. Myrland. 2003. Free-rider effects of generic advertising: the case of salmon. Agribusiness: an International Journal 19(3): 315-324.

Kinnucan, H.W. and O. Myrland. 2006. The effectiveness of antidumping measures: some evidence for farmed Atlantic salmon. Journal of Agricultural Economics 57(3): 459-477.

Kinnucan, H.W., H. Chang and M. Venkateswaran. 1993. Generic advertising wearout. Review of Marketing and Agricultural Economics 61(3): 401-415.

Lee, J.Y. and M.G. Brown. 1986. Economic effectiveness of brand advertising programs for U.S. orange juice in the European market: an error component analysis. Journal of Agricultural Economics 37(3): 385-394.

Miles, R.D. and F.A. Chapman. 2006. The benefits of fish meal in aquaculture diets. Fisheries and Aquatic Sciences Department, University of Florida, IFAS Extension, Gainesville, FL, USA. Available at: https://edis.ifas.ufl.edu/pdffiles/FA/FA12200.pdf

Myrland, O. and H.W. Kinnucan. 2000. Measuring the effects of the 1998/99 Pan-European salmon marketing campaign in Germany and France. In: R.S. Johnston and A.L. Shriver (eds.) Microbehavior and macroresults. Proceedings of the Tenth Biennial Conference of the International Institute of Fisheries Economics and Trade. July 10-14, 2000. Corvallis, OR, USA. Available at: https://ir.library.oregonstate. edu/concern/conference_proceedings_or_journals/jd472x515?locale $=$ en

Nerlove, M. and F.V. Waugh. 1961. Advertising without supply control: some implications of a study of the advertising of oranges. Journal of Farm Economics 43: 813-37.

Nerlove, M. and K.J. Arrow. 1962. Optimal advertising policy under dynamic conditions. Economica 26(114): 129-142.

Nielson, M. 2004. International market integration and demand: an analysis of the Norwegian and Danish herring market. Food Economics - Acta Agriculturae Scandinavica, Section C 1(3): 176-184.

Nielson, M., J. Smit and J. Guillen. 2009. Market integration of fish in Europe. Journal of Agricultural Economics 60(2): 367-385.

Nielson, M., J. Smit and J. Guillen. 2012. Price effects of changing quantities supplied at the integrated European fish market. Marine Resource Economics 27(2): 165-180.

Nilssen. F. and C. Elyestad. 2019. Konsekvenser ved langvarig lukking av det russiske markedet for sild (Consequences of long-term closure of the Russian herring market). R\&D Report No. 37. Nord Universitet, Bodø, Norway. Available at: http://hdl.handle.net/11250/2585756 
Norwegian Seafood Council (NSC). 2019. Data and information provided by direct communication with NSC and/or online from market insight: statistics. NSC, Tromsø, Norway.

Norwegian Seafood Council (NSC). 2020. Sustainability: stocks, managing our herring. NSC, Tromsø, Norway. Available at: https:/herring.fromnorway.com/sustainability/stocks/

Nostbakken, L. 2008. Sochastic modeling of the North Sea herring fishery under alternative management regimes. Marine Resource Economics 23(1): 65-86.

Nostbakken, L. and T. Biorndal. 2003. Supply function for North Sea herring. Marine Resource Economics 18(4): 345-361.

Pitcher, T.J., D. Kalikoski, K. Short, D. Varkey and G. Pramod. 2009. An evolution of progress in implementing ecosystem-based management fisheries in 33 countries. Marine Policy 33(2): 223-232.

Statistics Norway. 2019. Fisheries. Available at: https:/www.ssb.no/en/statbank/list/fiskeri.

Tveterås, S., F. Asche, M.F. Bellemare, M.D. Smith, A.G. Guttormsenm, A. Lem, K. Lien and S. Vannuccinik. 2017. Fish is food - the FAO's fish price index. PLOS ONE 7(5): e36731.

Tveteras, S., R. Tveteras and K. Lien. 2011. Food consumption changes in Russia: an analysis of regional demand for herring products. Food Economics - Acta Agriculturae Scandinavica, Section C 8(4): $222-232$.

Ward, R.M. 2006. Commodity checkoff programs and generic advertising. Choices 21(2): 55-60.

Ward, R.W. and B.L. Dixon. 1989. Effectiveness of fluid milk advertising since the Dairy and Tobacco Adjustment Act of 1983. American Journal of Agricultural Economics 71(3): 730-740.

Williams, G.W. and O. Capps Jr. 2006. Overview: commodity checkoff programs. Choices 2: 53-54.

Williams, G.W. and O. Capps Jr. 2020a. Advertising with supply control: some implications of Norwegian whitefish export promotion. Agricultural and Resource Economics Review 49(3): 558-585. https:// doi.org/10.1017/age.2019.25

Williams, G.W. and O. Capps Jr. 2020b. Generic promotion of Norwegian whitefish exports. Journal of International Food and Agribusiness Marketing 33(2): 123-151. https://doi.org/10.1080/0897443 8.2020 .1752876

Williams, G.W. and O. Capps Jr. 2020c. Generic promotion of Norwegian seafood exports. International Food and Agribusiness Management Review 23(3): 447-467. https://doi.org/10.22434/IFAMR2019.0160

Williams, G.W. and O. Capps Jr. and S.H. Lee. 2014. The return to soybean checkoff investments. Report to the Audit and Evaluation Committee of the United Soybean Board, St. Louis, MO, USA. Available at: http://www.unitedsoybean.org/wp-content/uploads/2021/06/USB-2014-ROI-Study.pdf

Williams, G.W., J.J. Reimer, R.M. Dudensing, B.A. McCarl, H.M. Kaiser and J. Somers. 2016. Economic impact of USDA export market development programs. Informa Economics, IEG, Prepared for U.S. Wheat Associates, USA Poultry \& Egg Export Council, Pear Bureau Northwest, and the USDA Foreign Agriculture Service. Available at: https://www.fas.usda.gov/sites/default/files/201610/2016econimpactsstudy.pdf

Wu, D.M. 1973. Alternative tests of independence between stochastic regressors and disturbances. Econometrics 41(4): 733-750.

Xie, J. 2008. Halo effect of Norwegian salmon promotion on EU salmon demand. IIFET Vietnam Proceedings, University of Tromsø, Tromsø, Norway. Available at: https://ir.library.oregonstate.edu/xmlui/bitstream/ handle/1957/36942/172.pdf? sequence=1

Xie, J. 2015. Testing advertising-induced rotation of demand curves in the EU salmon market. Aquaculture Economics Management 19(2): 175-191.

Xie, J., H.W. Kinnucan and O. Myrland. 2009. Demand elasticities for farmed salmon in world trade. European Review of Agricultural Economics 36(3): 425-445. 
